\title{
Development and Psychometric Evaluation of the Instrument: Attitudes Towards Organ Donor Advocacy Scale (ATODAS)
}

\author{
Anne Flodén ${ }^{*}, 1$, Annette Lennerling ${ }^{2}$, Isabell Fridh ${ }^{3}$, Magnus Rizell ${ }^{4}$ and Anna Forsberg ${ }^{2}$ \\ ${ }^{I}$ The Unit for Organ and Tissue Donation, Sahlgrenska University Hospital, Blå stråket 5, SE-413 45 Gothenburg, \\ Sweden \\ ${ }^{2}$ Institute of Health and Care Sciences, Sahlgrenska Academy at Gothenburg University, \& The Transplant Institute, \\ Sahlgrenska University Hospital, Gothenburg, Sweden \\ ${ }^{3}$ Institute of Health and Care Sciences, Sahlgrenska Academy at Gothenburg University, Gothenburg, Sweden \\ ${ }^{4}$ Department of Surgery, Sahlgrenska University Hospital, Gothenburg, Sweden
}

\begin{abstract}
The consequences of advocacy in nursing are critical when caring for a potential organ donor. No specific instrument has been available to measure attitudes toward organ donor advocacy. The aim of this study was to develop and psychometrically evaluate an instrument for measuring intensive and critical care (ICU) nurses' attitudes toward organ donor advocacy. The study was conducted in two stages: instrument development and instrument evaluation and refinement. A questionnaire was developed (Attitude Toward Organ Donor Advocacy Scale (ATODAS)), which was sent to half of all nurses working in ICUs (general-, neuro-, thoracic- or paediatric-) in Sweden ( $\mathrm{n}=1180)$. The final response rate was $42.5 \%(n=502)$. In order to explore validity and reliability, the expected scale dimensionality of the questionnaire was examined both by explorative principal component analysis (with oblique, varimax rotation) and by confirmatory multi-trait analysis. The confirmatory factor analysis indicated that the ATODAS could best be explained by five factors; Attitudes toward championing organ donation at a structural hospital level; Attitudes toward championing organ donation at a political and research level; Attitudes toward actively and personally safeguarding the will and wishes of the potential organ donor, Attitudes toward safeguarding the potential donor's will and wishes by a professional approach and Attitudes toward safeguarding the will and wishes of the relatives. This initial testing indicated that the ATODAS has good psychometric properties and can be used in future research to explore if interventions may influence attitudes and behaviors related to organ donor advocacy.
\end{abstract}

Keywords: Advocacy, brain death, intensive and critical care, nursing, organ donation, psychometric evaluation.

\section{INTRODUCTION}

End of Life Care in the intensive and critical care unit (ICU) involves caring for brain dead persons who by their death become potential organ donors and will possibly also donate their organs. Fridh et al. [1] have described the striving among ICU nurses to do their utmost in every aspect of the End of Life Care process. In some cases the death of a person where direct death criteria are present also implies the possibility of saving the lives of others by the donation of organs for transplantation. The rationale behind this study was that the concept of advocacy is critical for nurses who face the challenge of caring for a potential organ donor (POD) in order to facilitate organ donation (OD) in line with the wishes of the deceased. In spite of the importance of advocacy in nursing, there is a notable lack of instruments for measuring the phenomenon. No specific instrument has been available to measure attitudes towards organ donor advocacy. Although the different characteristics of advocacy have been fairly well described, this is not the case in

*Address correspondence to this author at the Unit for Organ and Tissue Donation, Sahlgrenska University Hospital, Blå stråket 5, SE-413 45 Gothenburg, Sweden; Tel: +46706-461267; Fax: +4631-415562;

E-mail: anne.floden@vgregion.se relation to organ donation and care of the potential organ donor in the ICU environment. The absence of systematic and structured measurements also hampers the possibility of making comparisons between groups of ICU nurses and evaluating the effects of various interventions. In addition to developing a context-specific instrument for self-assessment of attitudes towards organ donor advocacy, there is also a need to expand the knowledge of the advocacy experience and deepen understanding about the attitudes involved in the care of a POD in the ICU. The aim of this study was to develop and psychometrically evaluate an instrument for measuring ICU nurses' attitudes towards organ donor advocacy.

Today, patient advocacy is an important aspect of and a fundamental value in professional nursing [2]. The codes of nursing ethics reflect the on-going significance of advocacy $[3,4]$. However, advocacy is not the exclusive domain of the nursing profession despite the fact that it represents an important area in professional nursing. The concept of advocacy in general involves the activity of advocating, which among other things is synonymous with supporting, upholding, championing, backing, defending, justifying and promoting. The concept, most frequently cited as a component of nursing advocacy involves acting on behalf of patients, including intervening for them within a system, 
resulting in nurses' actions such as speaking, fighting for, championing and standing up for patients [5-7]. Advocacy is also referred to as being the patient's voice, protecting patients and acting as a guide $[8,9]$. According to Vaartio, Leino-Kilpi, Salantera and Suominen [10], advocacy is performed by the nurse due to personal or professional involvement as part of excellent nursing. One form of advocacy is so-called whistle blowing, where the nurse draws attention to the patient's rights and needs.

Lindahl \& Sandman [11] described the role of advocacy in the ICU. In relation to the patient, the meaning of advocacy is building a caring relationship involving meeting the private person and sharing a part of his/her life history. It also concerns a commitment to empowerment. In relation to patients' next of kin, it concerns making room for and interconnecting, involving information and translation, communication and collaboration with the family and relatives. The nurse guides, assists and involves the relatives. The role of advocacy in relation to colleagues means being a risk-taker and moral agent. According to Lindahl \& Sandman [11], the meaning of the role of advocacy in the ICU lies in a moral and existential response to another human being, an expression of caring. They argue that when a patient needs advocacy, the nurse responds in order to create dignity and comfort for the patient and his/her relatives. In conclusion, previous studies have defined advocacy as using expert knowledge to advocate effectively, challenge traditional health care power structures, empower patients and bridge the perceived communication gap between patients, other professionals and the health care system [5, 10-14].

\section{FRAMEWORK}

$\mathrm{Bu}$ and Jezewski [15] developed a mid-range theory of patient advocacy, which holds that advocacy is linked to the context and that the nurse advocates differently depending on the situation. In this theory, patient advocacy is viewed as a process or strategy consisting of a series of specific actions for preserving, representing and/or safeguarding patients' rights, best interests and values. Patient advocacy includes three broad core attributes:

- $\quad$ Safeguarding patients' autonomy - involves a series of specific actions aimed at respecting and promoting the patient's self-determination in situations where he/she is competent and willing to participate in selfcare activities

- $\quad$ Acting on behalf of patients - encompasses a series of specific actions that preserve and represent patients' values, benefits and rights in situations where the patient is incapable of doing so him/herself, e.g. due to unconsciousness, or when the patient chooses to allow the nurse to act on his/her behalf

- $\quad$ Championing social justice - refers to performing a series of actions to actively strive for change on behalf of individuals, communities and societies, with the aim of identifying inequalities and inconsistencies in the provision of care as set out in a clause in a legal instrument or hospital policy document.

The first two core attributes relate to different types of clinical situation. They are complementary, do not conflict with each other and represent the advocacy role at a micro social level. The third core attribute represents the advocacy role at the macro social level.

\section{MATERIALS AND METHODOLOGY}

This study was conducted in two stages: instrument development and instrument evaluation and refinement. The first stage included two steps:

a. defining the construction of attitudes towards organ donor advocacy

b. generating items and establishing content validity

The second stage included a postal survey and test of the construct validity and internal consistency reliability.

\section{STAGE ONE: INSTRUMENT DEVELOPMENT}

\section{Step 1: Defining the Construction of Attitudes Towards Organ Donor Advocacy}

As described above, the instrument was theoretically anchored in the framework of patient advocacy and guided by the instrument development performed by $\mathrm{Bu} \& \mathrm{Wu}$ [16]. Snowball [17] described advocacy activities as respecting patients' rights, representing or speaking up for the patients' points of view in the decision-making process if patients are unable or unwilling to speak up for themselves, protecting patients' dignity and privacy and saving them from interventions that might cause them distress. Applying this description to the situation of OD, participation in the donation process and caring for the potential or actual organ donor can be viewed as advocacy activities:

\section{Respecting the potential or actual organ donor's rights, representing or speaking up for his/her wishes as well as the relatives' points of view in the organ donation decision-making process. Protecting the potential or actual donor's dignity as well as the relatives' privacy and defending them from interventions that might cause them distress.}

The theoretical definition of attitudes towards organ donor advocacy (ATODA) was developed on the basis of Ajzen and Fishbein's [18] definition of attitude in their theory of reasoned action (TRA) and by applying $\mathrm{Bu}$ and Jezewski's [15] theory of patient advocacy. According to TRA, a person's attitude towards performing a given behaviour refers to the degree to which he/she has a positive or negative perception of performing it. The construct of attitudes towards organ donor advocacy is in this study defined as follows:

It is the ICU nurse's own decision whether he or she is in favour of or against participating in organ donation and caring for the potential or actual donor, as well as preserving, representing and safeguarding the donor's and his/her relatives' rights, best interests and values after death.

This includes three dimensions:

- $\quad$ Safeguarding the potential donor's will and wishes

- Safeguarding the will and wishes of the relatives of potential donors 
- $\quad$ Championing social justice (e.g. ensuring that all clauses in legal instruments or hospital policy documents on organ donation are adhered to)

According to Ajzen and Fishbein [18], individuals' attitudes are a significant predictor of their behavioral intention and actual performance of the behaviour. Since an extensive literature review [19] revealed that the attitudes among ICU staff might be a barrier to OD, it is important to be able to study these attitudes in a systematic way. One assumption is that individual nurses' attitudes towards organ donor advocacy are a significant predictor of their behavioral intention and actual performance in the OD situation.

\section{Step 2: Generating Items and Establishing Content Validity}

Initially, an item pool of 55 items measuring ICU nurses' attitudes towards organ donor advocacy was generated based on three previous studies within the context of Swedish legislation and OD organization at a national level [20-22] and on an extensive literature review [19]. A panel of seven experts was formed to assess the content validity of the 55item scale. The seven experts were two nurse researchers in the intensive and critical care field, four clinical ICU nursing experts, one of whom was a $\mathrm{PhD}$ student and another a senior researcher and expert on item construction. The experts on the panel were given a rating form with the theoretical definition as well as a delineation of the three dimensions, objectives and items. They were asked to review content relevance, clarity and domain coverage as well as to rate each item on a 4-point scale (from 1=not relevant to $4=$ very relevant). Calculation of the content validity index (CVI) was based on agreement between the evaluators. Content validity was validated with reference to Lynn's [23] criteria: with seven evaluators, an item rated as either 3 (relevant and needs little revision) or 4 (very relevant) by at least six evaluators $(>86 \%)$ is considered valid and included in the scale. With seven evaluators, the CVI of a scale is the proportion of total items rated by six or more evaluators as either 3 or 4 . The CVI for the entire ATODA scale was $82 \%$. A CVI score of $80 \%$ or higher is generally considered reasonable content validity [24].

\section{STAGE TWO: INSTRUMENT EVALUATION AND REFINEMENT}

In the second stage, two studies were conducted, a pilot study $(n=20)$ and main data collection by means of a large survey. A questionnaire consisting of the 55-item ATODA scale and a set of demographic questions was prepared for both the pilot study and the main study. Since the ATODA scale was designed to be applicable to all ICU nurses with direct patient care experience, the instrument was tested on a sample of ICU nurses. Their patient advocacy role is especially important due to the unique needs and issues of patients in intensive care, such as vulnerability. When the vulnerable patient dies and is diagnosed as brain dead, an opportunity for OD may occur. In situations of OD from a deceased patient in the ICU, the major area of ethical concern involves the diagnosis of death. Issues include the identification and diagnosis of brain death and the responsibility to ask whether or not the deceased had expressed a wish to donate his/her organs. Additional issues concern attitudes and beliefs about the death itself [25].
The concept of 'potential organ donor' (POD) is used to denote a patient who is declared dead on the basis of brain death criteria, treated by a ventilator in an ICU setting and considered medically suitable to become an organ donor, but where the decision about organ donation has not yet been made [26]. Once the medical suitability of a potential donor is established, consent to organ donation needs to be explored. According to the Swedish Transplantation Act, it is the attitude of the deceased to organ donation that is paramount. The wish can be expressed verbally, or through the national donor registry and/or a completed donor card. The last wish expressed is valid. Consent is presumed in cases where the wish of the deceased is not known. Next of kin have the right to veto only in cases where the wish of the deceased is unknown $[27,28]$. Failure to raise the question of OD will result in ICU staff deciding against it without investigating the wish of the deceased. If the deceased patient's wish was to donate his/her organs after death, then he/she is deprived of this possibility despite the fact that The Health and Welfare Act highlights the need for an ethical approach to nursing and caring, where respect for the deceased's autonomy is crucial [29].

In the pilot study, a total of 20 ICU nurses from two general ICUs and one neurosurgical intensive care unit (NICU) participated. There were ten respondents from one university hospital, involving both general ICU and NICU nurses, and ten from a regional hospital. A unit leader from each ICU setting randomly selected nurses to participate in the pilot study. After the review by the expert group and the pilot study, the number of items was reduced by eight, from 55 to 47 , in order to increase clarity and relevance. The version of the ATODAS used for the main data collection included 15 items aimed at measuring attitudes towards Safeguarding the potential donor's will and wishes, 15 items dealing with attitudes towards Acting on behalf of the potential or actual donor as well as his/her relatives and 17 items covering attitudes towards Championing social justice. A 6-point Likert-type scale was used, ranging from very negative to very positive attitudes towards organ donor advocacy. Responses were scored on a 6-point scale ranging from strongly disagree (1) to strongly agree (6). Scoring was reversed for one negatively worded item so that a high score reflected strong support for advocacy.

\section{Sample and Procedure}

Tabachnick and Fidell [30] indicated that at least 300 cases are required for a factor analysis. However, MacCallum, Widaman, Zhang and Hong [31] suggested that a sample size of 500 or more is preferable. An instrument containing about 50 items should therefore be tested on a sample of approximately 500 participants. For the main data collection, the inclusion criterion was being a nurse working in an ICU. The participants were identified from an existing register administered by the Swedish Association of Health Professionals (SAHP), which is a trade union and professional organization for registered nurses, midwives, biomedical scientists and radiographers. The SAHP register included a random sample of $50 \%$ of ICU nurses taken from their member registry. In November 2010, the ATODAS questionnaire was sent to $50 \%$ of all nurses working in a general ICU, NICU, thoracic ICU and paediatric ICU in Sweden $(n=1180)$ in order to obtain approximately 500 
completed questionnaires. As a low response rate (20-30\%) was anticipated, the SAHP membership was over-sampled. Anonymity of respondents was assured, and no identifier was marked on the distributed questionnaires. After the first mailing and one reminder, 445 participants responded. A second reminder was sent, which increased the number of respondents by 57 , giving a final response rate of $42.5 \%$ (502 out of 1180). We were unable to analyse the external dropout rate of $57.5 \%(\mathrm{n}=678)$, as the questionnaires were sent anonymously, which made it impossible to determine the reasons for declining participation. However, as 74 nurses contacted us to decline participation, as they no longer worked in the ICU (already excluded), one explanation for dropout may be that the SAHP membership registry was not sufficiently updated. We also suspect a systematic dropout since the issue of organ donor advocacy is highly sensitive and demanding. The respondents might be professionals with a strong opinion about organ donor advocacy and a willingness to express their views. On the other hand, the dropouts may represent professionals who do not reflect on these matters and therefore are not able to share their points of view.

No questionnaires had to be excluded due to excessive missing data $(>30 \%)$ within one or more subscales, thus 502 questionnaires were used in the analysis. Demographic data collected in the questionnaire included age, gender, ICU work experience, educational level, type of hospital (i.e. local general hospital or university hospital) and ICU. A detailed, demographic profile of the participants is presented in Table 1a-d. After the main data collection $(n=502)$, factor analysis was employed to examine construct validity and internal consistency reliability. The ATODA scale was then revised based on the results of the factor analysis.

Table 1a. Demographics of the Swedish ICU Nurses $(n=502)$

\begin{tabular}{|l|l|}
\hline Mean Age (Range) & 47 years, $(24-66$ years) \\
\hline Mean ICU work experience & 16 years $(0.5-40$ years $)$ \\
\hline Female & $88.5 \%(\mathrm{n}=445)$ \\
Male & $9.5 \%(\mathrm{n}=48)$ \\
Missing responses & $2 \%(\mathrm{n}=9)$ \\
\hline Local hospital & $26.5 \%(\mathrm{n}=133)$ \\
Regional hospital & $33.5 \%(\mathrm{n}=169)$ \\
University hospital & $37 \%(\mathrm{n}=185)$ \\
Missing responses & $3 \%(\mathrm{n}=15)$ \\
\hline General intensive care unit (ICU) & $74 \%(\mathrm{n}=373)$ \\
Neurosurgical intensive care unit & $7 \%(\mathrm{n}=34)$ \\
Thoracic intensive care unit & $8 \%(\mathrm{n}=40)$ \\
Paediatric intensive care unit & $2 \%(\mathrm{n}=11)$ \\
Other type of ICU e.g. infection ICU & $7.5 \%(\mathrm{n}=37)$ \\
Missing responses & $1.5 \%(\mathrm{n}=7)$ \\
\hline Current position & \\
Unit manager, Assistant unit manager & $0.5 \%(\mathrm{n}=2)$ \\
Section leader & $3.5 \%(\mathrm{n}=18)$ \\
Unit teacher & $0.5 \%(\mathrm{n}=2)$ \\
ICU nurse, with special responsibility for donation & $5.5 \%(\mathrm{n}=27)$ \\
ICU staff nurse & $68 \%(\mathrm{n}=342)$ \\
Other position & $20.5 \%(\mathrm{n}=104)$ \\
Missing responses & $1.5 \%(\mathrm{n}=7)$ \\
\hline
\end{tabular}

Table 1b. Level of Education Among Swedish ICU Nurses $(n=502)$

\begin{tabular}{|l|l|}
\hline Registered nurse with a specialist nursing degree & \\
Yes & $97.5 \%(\mathrm{n}=488)$ \\
No & $1.5 \%(\mathrm{n}=8)$ \\
Missing responses & $1 \%(\mathrm{n}=6)$ \\
\hline Bachelor's degree & \\
Yes & $38 \%(\mathrm{n}=191)$ \\
No & $60.5 \%(\mathrm{n}=303)$ \\
Missing responses & $1.5 \%(\mathrm{n}=8)$ \\
\hline Master's degree or higher & \\
Yes & $10 \%(\mathrm{n}=49)$ \\
No & $87 \%(\mathrm{n}=438)$ \\
Missing responses & $3 \%(\mathrm{n}=15)$ \\
\hline
\end{tabular}

Table 1c. Work Experience Among Swedish ICU Nurses $(\mathbf{n}=\mathbf{5 0 2})$

\begin{tabular}{|l|l|}
\hline $\begin{array}{l}\text { Experiences of caring for a brain dead patient on } \\
\text { mechanical ventilation }\end{array}$ & \\
Never & $8.5 \%(\mathrm{n}=43)$ \\
$1-5$ times & $52 \%(\mathrm{n}=255)$ \\
$6-10$ times & $10.5 \%(\mathrm{n}=52)$ \\
$>10$ times & $8 \%(\mathrm{n}=41)$ \\
Missing responses & $2 \%(\mathrm{n}=9)$ \\
\hline Participation in discussions about OD with & \\
relatives & \\
Never & $29.5 \%(\mathrm{n}=148)$ \\
$1-5$ times & $51 \%(\mathrm{n}=255)$ \\
$6-10$ times & $10.5 \%(\mathrm{n}=52)$ \\
$>10$ times & $8 \%(\mathrm{n}=41)$ \\
Missing responses & $1 \%(\mathrm{n}=6)$ \\
\hline
\end{tabular}

Table 1d. Personal Experience of Organ Donation and Transplantation $(n=502)$

\begin{tabular}{|l|l|}
\hline The nurse him/herself, family and/or friends have & \\
personal experience of organ donation & $6 \%(\mathrm{n}=31)$ \\
Yes & $91.5 \%(\mathrm{n}=459)$ \\
No & $2.5 \%(\mathrm{n}=12)$ \\
Missing responses & \\
\hline The nurse him/herself, family and/or friends have & \\
personal experience of organ transplantation & $10 \%(\mathrm{n}=51)$ \\
Yes & $87.5 \%(\mathrm{n}=439)$ \\
No & $2.5 \%(\mathrm{n}=12)$ \\
Missing responses & \\
\hline
\end{tabular}

\section{Statistical Analysis to Examine Construct Validity and Scale Reliability}

Data were analysed with the SPSS version 18.0 and the Multi-trait Analysis Program version 2 [32]. In order to explore validity and reliability, the expected scale dimensionality of the questionnaire was examined both by explorative principal component analysis (with oblique 
varimax rotation) and by confirmatory multi-trait analysis. In the explorative principal component analysis, three strategies; Cattell's scree plot, absorption of variance and meaningfulness of factors [33], were used interactively to determine the number of tentative factors to retain. These factors were then tested by multi-trait analysis. Here the hypothesized internal item-scale structure was examined, i.e. convergent and discriminatory validity. Convergent validity refers to the consistency of the items expected to measure a scale (factor). It was tested by computing the item correlations with their expected factor corrected for overlap. A common criterion is item-scale correlations of at least 0.40 [32]. Discriminatory validity was tested by computing the proportion of items that had a higher or significantly higher correlation with their expected (hypothesized) scale compared with the other scales (success rate). The item-scale structure that was the best compromise between the results of the multi-trait analysis and the explorative factor analysis was retained. Scale reliability was further estimated using Cronbach's alpha. According to a conventional rule, this coefficient should exceed at least .70 [34].

\section{Ethical Considerations}

According to Swedish law at the time of the study, ethical approval was not required since the study did not involve patients [35]. Nevertheless, the ethical aspects are in accordance with the Helsinki Declaration [36] and the Ethical Guidelines for nursing research in the Nordic countries [37] regarding the requirements of information, consent, confidentiality and utility.

\section{RESULTS}

All 47 ATODAS items were subjected to an exploratory principal component analysis followed by oblique varimax rotation. Prior to performing the analysis, the suitability of the data for factor analysis was assessed. Inspection of the correlation matrix revealed that most of the item-total coefficients were above .30. The highest inter-item correlation coefficient was .78 . We performed a principal component analysis, testing between three and ten factors in order to obtain a solution with the most optimal scale variance, which resulted in a five- rather than the three-factor solution initially hypothesized. In the five-factor solution, all factors had eigenvalues greater than 1.0. The rotated fivefactor solution revealed the presence of a simple structure, with each factor showing a number of strong loadings and most variables loading substantially $(>.35)$ on only one factor, with a difference in loading on the other factors of at least .20. The total scale variance explained by the five factors was $41.9 \%$.

When a loading criterion of .40 was applied, 10 items that loaded .40 or above on factor one only were categorized in subscale one and labeled Attitudes towards championing organ donation at a structural hospital level (10 items). An additional 5 items, originally classified into the dimension Championing social justice, were categorized in subscale two and labeled Attitudes towards championing organ donation at a political and research level. Fifteen items originally classified as a measure of Safeguarding the potential donor's will and wishes were now reclassified into two different factors labeled Attitudes towards actively and personally safeguarding the will and wishes of the POD (6 items) and Attitudes towards safeguarding the potential donor's will and wishes by a professional approach (7 items). The remainder of the fifteen items originally classified as a measure of acting on behalf of the potential or actual donor as well as his/her relatives were organized under the label Attitudes towards safeguarding the will and wishes of the relatives ( 8 items). Cronbach's alpha was calculated to examine the internal consistency reliabilities of the remaining 36 items distributed across the five factors based on the sample of 502 respondents. Since the Cronbach's alpha values for three of the five factors were high, four more items were removed from the item pool due to poor squared multiple correlation values. The final satisfactory factor loadings for the five relevant factors together with their Cronbach's alpha values are presented in Table 2. The five factor solution was further strengthened by analysis of correlations between the various factors. There was a reasonable correlation between all factors except for the one aimed at measuring attitudes towards championing OD at a political and research level, as shown in Table $\mathbf{3}$. The results indicated satisfactory internal consistency of the entire ATODA scale and its factors for the five-factor model chosen.

\section{DISCUSSION}

In this study, a measure of ICU nurses' attitudes towards organ donor advocacy, the Attitude Towards Organ Donor Advocacy Scale (ATODAS) was developed, tested and refined. The ATODAS was initially conceptualized in three dimensions; Safeguarding the potential donor's will and wishes (SPDW), Safeguarding the potential donor's relatives' will and wishes (SPRW) and Championing social justice (CSJ), corresponding to three core attributes of patient advocacy [15]. Results supported the validity and reliability of the ATODAS as a multidimensional scale for measuring ICU nurses' attitudes towards advocacy on behalf of potential and actual organ donors. However, since no testretest has yet been performed, we do not know at this point whether the total and its five subscales are stable over time. Further tests are needed.

Construct validity of the ATODAS was examined using exploratory principal component analysis (with oblique varimax rotation) and confirmatory multi-trait analysis. Exploratory factor analysis of the 47-item scale resulted in a five-factor solution explaining the highest proportion of the variance. This solution at first appeared incongruent with the initially hypothesized three-factor structure of the construct of attitudes towards organ donor advocacy. However, after scrutinizing the five factors, it became evident that they still covered the initially hypothesized three-factor structure of the construct but in a more nuanced way. Championing social justice involves advocating at a macro social level, which, on the one hand, may involve a structural level at the hospital where one works and, on the other, a political or research level. Thus there is a possibility to advocate on two different macro social levels in relation to OD. At a micro social level, it is possible to advocate in relation to the donor's will and wishes in a clearly action oriented way measured by 6 items in a factor labeled Attitudes towards actively and personally safeguarding the will and wishes of 
Table 2. Rotated Component Matrix with Cronbach's Alfa Values

\begin{tabular}{|c|c|c|c|}
\hline ATODA Factors & Items & Item Scale Correlation & Cronbach's Alfa \\
\hline \multirow{10}{*}{$\begin{array}{l}\text { 1. Attitudes towards } \\
\text { championing OD at a } \\
\text { structural hospital level }\end{array}$} & $\begin{array}{l}\text { In my ICU ward I help develop guidelines that take account of the } \\
\text { situation of potential donors and the needs of their relatives. }\end{array}$ & .78 & \multirow[t]{10}{*}{.90} \\
\hline & $\begin{array}{l}\text { I co-operate with other professionals outside my ICU (e.g. X-ray } \\
\text { and lab) to improve organ donation guidelines. }\end{array}$ & .76 & \\
\hline & $\begin{array}{l}\text { If the need arises, I take action on a structural level to change the } \\
\text { organ donation policy document. }\end{array}$ & .72 & \\
\hline & $\begin{array}{l}\text { If the need arises, I would resort to other actions to achieve good } \\
\text { routines for organ donation, e.g. training of staff, a reflection } \\
\text { group for ethical issues etc. }\end{array}$ & .71 & \\
\hline & $\begin{array}{l}\text { If the need arises, I take part in work to improve the organ } \\
\text { donation guidelines in my ICU ward. }\end{array}$ & .70 & \\
\hline & $\begin{array}{l}\text { If the need arises, I point out the importance of organ donation } \\
\text { guidelines to the ICU managers. }\end{array}$ & .70 & \\
\hline & $\begin{array}{l}\text { I employ available scientific knowledge to ensure that the method } \\
\text { of working in connection with organ donation is evidence based. }\end{array}$ & .65 & \\
\hline & $\begin{array}{l}\text { I promote communication and cooperation between various } \\
\text { professional categories in the care of a potential donor. }\end{array}$ & .63 & \\
\hline & I discuss and promote organ donation outside my ICU. & .62 & \\
\hline & $\begin{array}{l}\text { I communicate problems that arise in relation to organ donation to } \\
\text { the senior management of my unit/department. }\end{array}$ & .60 & \\
\hline \multirow{4}{*}{$\begin{array}{l}\text { 2. Attitudes towards } \\
\text { championing OD at a } \\
\text { political and research level }\end{array}$} & I take part in decision-making that affects organ donation. & .69 & \multirow[t]{4}{*}{.62} \\
\hline & $\begin{array}{l}\text { I am considering starting to work politically to promote organ } \\
\text { donation. }\end{array}$ & .67 & \\
\hline & I participate in research that affects organ donation. & .55 & \\
\hline & $\begin{array}{l}\text { If possible, I would take part in research that influences guidelines } \\
\text { and policies regarding organ donation. }\end{array}$ & .47 & \\
\hline \multirow{5}{*}{$\begin{array}{l}3 \text { Attitudes towards actively } \\
\text { and personally safeguarding } \\
\text { the will and wishes of the } \\
\text { POD }\end{array}$} & $\begin{array}{c}\text { I will take action if the medical treatment of the potential donor is } \\
\text { unsuitable. }\end{array}$ & .74 & \multirow[t]{5}{*}{.80} \\
\hline & $\begin{array}{l}\text { I question inadequate care of a potential donor performed by a } \\
\text { nurse or doctor in my ward. }\end{array}$ & .73 & \\
\hline & $\begin{array}{l}\text { I call attention to any team member who hinders the correct and } \\
\text { consistent care of the potential donor. }\end{array}$ & .72 & \\
\hline & $\begin{array}{c}\text { I will argue against all forms of unethical treatment of a potential } \\
\text { donor. }\end{array}$ & .68 & \\
\hline & $\begin{array}{l}\text { I discuss with the intensivist in attendance about the consequences } \\
\text { of his/her decision(s) regarding the potential donor. }\end{array}$ & .59 & \\
\hline \multirow{6}{*}{$\begin{array}{l}\text { 4. Attitudes towards } \\
\text { safeguarding the potential } \\
\text { donor's will and wishes by a } \\
\text { professional approach }\end{array}$} & If known to me, I express the will of the potential donor & .73 & \multirow[t]{6}{*}{.73} \\
\hline & $\begin{array}{l}\text { I bring the will of the deceased and/or relatives regarding organ } \\
\text { donation to the attention of the intensivist in charge and the doctor } \\
\text { with responsibility for patients (PAL). }\end{array}$ & .72 & \\
\hline & $\begin{array}{l}\text { It is my responsibility to represent the potential donor throughout } \\
\text { the donation process. }\end{array}$ & .66 & \\
\hline & It is my duty to respect the will of the potential donor. & .59 & \\
\hline & $\begin{array}{l}\text { I am receptive to and respect the will of the potential donor even if } \\
\text { I do not share his/her view. }\end{array}$ & .59 & \\
\hline & $\begin{array}{l}\text { I make colleagues in my shift aware of the will of the deceased } \\
\text { and/or next of kin regarding organ donation. }\end{array}$ & .47 & \\
\hline
\end{tabular}


(Table 2) contd.....

\begin{tabular}{|c|c|c|c|}
\hline ATODA Factors & Items & Item Scale Correlation & Cronbach's Alfa \\
\hline \hline $\begin{array}{c}\text { 5. Attitudes towards } \\
\text { safeguarding the will and } \\
\text { wishes of the relatives }\end{array}$ & I help next of kin to weigh the reasons for and against organ \\
donation. & \begin{tabular}{c}
.71 \\
\cline { 2 - 4 }
\end{tabular} & I discuss any consequences of next of kin's decisions with them. & .65 \\
\cline { 2 - 4 } & $\begin{array}{c}\text { I try to help next of kin to reach a decision they can live with. } \\
\text { When there is a possibility of organ donation, it is my duty to } \\
\text { explain the meaning of the Transplantation Act to next of kin, } \\
\text { including their rights. }\end{array}$ & .49 \\
\cline { 2 - 4 } & $\begin{array}{c}\text { I provide information on a regular basis to next of kin about the } \\
\text { care of the potential donor. }\end{array}$ & .47 \\
\cline { 2 - 4 } & $\begin{array}{c}\text { I ensure that next of kin understand the medical actions that will } \\
\text { be taken when the deceased has been identified as a medically } \\
\text { suitable donor. }\end{array}$ & .43 \\
\cline { 2 - 4 } & $\begin{array}{c}\text { I remind other staff members involved in the care of the potential } \\
\text { donor that next of kin have a right to continuous information. }\end{array}$ & .42 \\
\hline
\end{tabular}

Table 3. Correlations Between the Factors of ATODAS Measuring Five Factors:

1. Attitudes Towards Championing OD at a Structural Hospital Level (ATODA-SHL)

2. Attitudes Towards Championing OD at a Political and Research Level (ATODA-PRL)

3. Attitudes Towards Actively and Personally Safeguarding the Will and Wishes of the POD (ATODA-APS)

4. Attitudes Towards Safeguarding the Potential Donor's Will and Wishes by a Professional Approach (ATODA-SPPA)

5. Attitudes Towards Safeguarding the Will and Wishes of the Relatives (ATODA-SWR)

\begin{tabular}{|c|c|c|c|c|c|}
\hline & ATODA-SHL & ATODA-PRL & ATODA-APS & ATODA-SPPA & ATODA-SWR \\
\hline 1.ATODA-SHL & & $.41^{* *}$ & $.50^{* *}$ & $.22^{* *}$ & .07 \\
\hline 2.ATODA-PRL & $.41^{* *}$ & & $.18^{* *}$ & $.35^{* *}$ & $.20^{* *}$ \\
\hline 3.ATODA-APS & $.50^{* *}$ & $.18^{* *}$ & & $.47^{* *}$ \\
\hline 4.ATODA-SPPA & $.22^{* *}$ & .07 & $.35^{* *}$ & $.37^{* *}$ \\
\hline 5.ATODA-SWR & $.50^{* *}$ & $.20^{* *}$ & $.47^{* *}$ & $.37^{* *}$ & \\
\hline
\end{tabular}

the POD or by adopting a professional but less active approach, measured by 7 items in a factor labeled Attitudes towards safeguarding the potential donor's will and wishes by means of a professional approach. Finally, the structure of the construct was also covered at the micro social level by an eight-item factor measuring advocacy in relation to the donor's relatives, labeled Attitudes towards safeguarding the will and wishes of the relatives. In conclusion, the confirmatory factor analysis indicated that the ATODAS could be best explained by five factors. It was also found that the Cronbach's alpha coefficients of the final 32-item ATODAS and its subscales possessed satisfactory internal consistency ranging from .62-.90. Although an alpha of at least .70 is desirable, a cut-off of .60 is common in exploratory research. The formula for alpha also takes into account the number of items. That is, when the number of items in a scale is higher, alpha will be higher even when the estimated average correlations are equal. As the number of items rises, alpha rises [38].

Although the analyses demonstrated that the five-factor ATODAS possessed good psychometric properties, there are some issues that need to be addressed. Firstly, this is a highly context specific instrument for measuring attitudes towards advocating activities. The multi-dimensional items only concern ICU nurses' advocating activities during an extremely limited time frame, i.e. the period during which a potential or actual donor receives after death care. We argue that this instrument could be very useful when attempting to grasp the complex content of attitudes towards organ donor advocacy, which at times involves ethical and delicate aspects of ICU nurses' professional actions. However, the ATODAS is not very useful for covering aspects of general end of life care in the ICU. Secondly, as expected, the response rate was low. In a previous study [21] we used exactly the same data collection procedure but a different instrument, resulting in a much higher response rate. In the latter case, the items were formulated in a more general manner, not involving aspects of advocacy, one's own moral obligations or standpoints. In contrast, almost every item in the ATODAS demands a more or less deep reflection regarding one's professional and moral responsibility. Therefore we assume that the low response rate was due to a systematic dropout, where only nurses with a firm opinion about organ donor advocacy chose to participate. When testing the ATODAS further, this aspect needs to be deeply reflected upon and dealt with. 
Thirdly, the ATODAS needs further testing regarding reliability, i.e. test-retest, and sensitivity to change. Today we do not know whether or not the instrument can detect changes in attitudes towards organ donor advocacy after interventions, for example, educational programs for ICU nurses on the subject of OD. A test-retest will reveal whether it is possible to explore if attitudes towards organ donor advocacy remain stable over time or whether they are affected by professional experience in general and the experience of caring for an organ donor in particular. In summary, the results of testing the ATODAS using exploratory and confirmatory factor analysis support and nuance the mid-range theory of patient advocacy proposed by $\mathrm{Bu}$ and Jezewski [15]. Organ donor advocacy consists of multi-dimensional behaviours, and ICU nurses' attitudes towards advocating on behalf of potential or actual donors may vary with different clinical situations and ICU settings, which can be classified into the three core attributes described above. The theory suggests that nurses who perform certain patient advocacy behaviours in some clinical situations, such as safeguarding patient autonomy, may not necessarily exhibit other patient advocacy behaviours under different clinical circumstances, such as championing social justice. There is a need to study what causes different attitudes and behaviours related to organ donor advocacy among ICU nurses in different settings. Do those with low scores on organ donor advocacy lack sufficient knowledge or are they not aware that the OD situation strongly requires advocating actions? Although the ATODAS needs further refinement, this initial test suggests that it can be used in future research to explore these and other factors that may influence attitudes and behaviours related to organ donor advocacy.

\section{ACKNOWLEDGEMENT}

The corresponding author thankfully acknowledges funding support from 'Paul Frankenius foundation concerning kidney disease and. from Lennart Jacobssons foundation for research in kidney transplantation.

The authors give sincere thanks to: Lars-Olof Persson, $\mathrm{PhD}$, associate professor, Sahlgrenska Academy at Gothenburg University, for great and thorough work helping us with the statistics and to G. Nilsson for superb language review. None of the previous mentioned, had no other involvement in the study.

Also a thanks to the expert group helping us during the development process of the instrument.

\section{CONFLICT OF INTEREST}

There are no conflicts of interest of any kind.

\section{REFERENCES}

[1] Fridh I, Forsberg A, Bergbom I. Doing one's utmost: nurses description of caring for dying patients in an intensive care environment. Intens Crit Care Nurs 2009; 25: 233-41.

[2] Hanks R. Development and testing of an instrument to measure protective nursing advocacy. Nurs Ethics 2010; 17(2): 255-67.

[3] American Nurses Association. The Code of Ethics. Washington DC: ANA 2001.

[4] International Council of Nurses. The ICN code of ethics for nurses. Geneva: ICN, 2006.
[5] Chafey K, Rhea M, Shannon A, Spencer S. Characterizations of advocacy by practicing nurses. J Professional Nurs 1998; 14: 4352.

[6] Foley B, Minick P, Kee C. Nursing advocacy during a military operation. West J Nurs Res 2000; 22: 492-507.

[7] Hanks R. The lived experience of nursing advocacy: a descriptive pilot study. Nurs Ethics 2008; 22: 492-507.

[8] Sellin S. Out on a limb: a qualitative study of patient advocacy in institutional nursing. Nurs Ethics 1995; 2: 19-29.

[9] McSteen K, Peden-McAlpine C. The role of the nurse as advocate in ethically difficult care situation with dying patients. J Hosp Palliative Nurs 2006; 8: 259-69.

[10] Vaartio H, Leino-Kilpi H, Salantera S, Suominen T. Nursing advocacy: how it is defined by patients and nurses, what does it involve and how is it experienced? Scand J Caring Sci 2006; 20: 282-92.

[11] Lindahl B, Sandman P. The role of advocacy in critical care nursing: A caring response to another. Intens Crit Care Nurs 1998; 14: $179-86$.

[12] Mallik M. Advocacy in nursing: perceptions of practicing nurses. J Clin Nurs 1997; 6: 303-13.

[13] Hellwig SD, Yam M, Di Guilio M. Nurse case managers' perception of advocacy: a phenomenological inquiry. Lippincott Case Managers 2003; 8(2): 53-63.

[14] O'Connor T, Kelly B. Bridging the gap: a study of general nurses' perceptions of patient advocacy in Ireland. Nurs Ethics 2005; 12: 453-67.

[15] $\mathrm{Bu} \mathrm{X}$, Jezewski M. Developing a mid-range theory of patient advocacy through concept analysis. J Adv Nurs 2007; 57: 101-10.

[16] $\mathrm{Bu} \mathrm{X}, \mathrm{Wu} \mathrm{YB}$. Development and psychometric evaluation of the instrument: attitude towards patient advocacy. Res Nurs Health 2008; 31: 63-75.

[17] Snowball J. Asking nurses about advocating for patients: "Reactive" and "proactive" accounts. J Adv Nurs 1996; 24: 67-75.

[18] Ajzen I, Fishbein M. Understanding attitudes and predicting social behaviour. Englewood Cliffs, NJ: Prentice Hall 1980.

[19] Flodén A, Kelvered M, Frid I, Backman L. Causes why organ donation was not carried out despite the deceased being positive to donation. Transplant Proc 2006; 38 (8): 2619-21.

[20] Flodén A, Forsberg A. A phenomenographic study of ICU-nurses' perceptions of and attitudes to organ donation and care of potential donors. Intens Crit Care Nurs 2009; 25(6): 306-13.

[21] Flodén A, Persson L-O, Rizell M, Sanner M, Forsberg A. Attitudes to organ donation among Swedish ICU nurses. J Clin Nurs 2011a. doi: 10.1111/j.1365-2702.2011.03756.x.

[22] Flodén A, Bergh M, Forsberg A. Swedish ICU nurses' perceptions of responsibilities and organization in relation to organ donation - a phenomenographic study. Intens Crit Care Nurs 2011b. doi:10.1016/j.iccn.2011.08.002.

[23] Lynn MR. Determination and quantification of content validity. Nurs Res 1986; 35: 382-385.

[24] Polit D, Beck C. Essentials of Nursing Research. $7^{\text {th }}$ ed. Philadelphia: Lippincott Williams \& Wilkins 2010.

[25] Smith J. Organ donation in intensive care - a look at the ethical issues. Intens Crit Care Nurs 1992; 8: 227-33.

[26] The Swedish Council for organ and tissue donation. Potential donors in Sweden. Möjliga donatorer i Sverige - en nationell kartläggning av dödsfall inom intensivvården, 2008. Available from: http://www.donationsradet.se/startsida/nyheter/Sidor/mojliga donatorerisverige-ennationellkartlaggningavdodsfallinomintensivva rden.aspx [accessed 13 May 2011] [in Swedish]

[27] SFS 1995:831. The Swedish Transplantation Act. Svensk författningssamling.. Lag om transplantation m. m. Available from: http:// www.notisum.se/rnp/sls/lag/19950831.htm [accessed 13 May 2011] [in Swedish]

[28] SOSFS 2009:30 (M). The National board of Health and Welfare. Donation och tillvaratagande av organ, vävnader och celler. Available from: http://www.socialstyrelsen.se/sosfs/2009-30/Docu ments/2009_30.pdf [accessed 13 May 2011] [in Swedish]

[29] Ministry of Health and Social Affairs. Socialdepartementet. Hälso och Sjukvårdslag 1982:763. Available from: http://www.notisum.se /Pub/Doc.aspx?url=/rnp/sls/lag/19820763.htm [accessed 15 May 2011] [in Swedish]

[30] Tabachnick B, Fidell L. Using multi-variate statistics. $4^{\text {th }}$ ed. Boston: Allyn \& Bacon 2001. 
[31] MacCallum RC, Widaman KF, Shang S, Hong S. Sample size in factor analysis. Psychol Methods 1999; 4: 84-99.

[32] Hays RD, Hayashi T, Carson S, Ware JE. User's guide for the multi-trait analysis program (MAP). The Rand Publication Series 1988.

[33] Gorsuch RL. Factor analysis. Hillsdale NJ: Lawrence Erlbaum Associates 1983.

[34] Nunnally JC, Bernstein IH. Psychometric Theory. 3rd ed. New York: McGraw-Hill Publishing Company 1994.

[35] SFS 2003:460. The Act concerning the Ethical Review of Research Involving Humans. Svensk författningssamling. Lag om etikprövning som avser forskning på människor. Available from: http://www.notisum.se/rnp/sls/lag/20030460.htm [accessed 1 June 2011] [in Swedish]

[36] World medical association. Declaration of Helsinki - Ethical Principles for Medical Research Involving Human Subjects, 2008. Available from: http://www.wma.net/en/30publications/10policies/ b3/index.html [accessed 1 June 2011]

[37] Northern nurses' federation. Ethical guidelines for nursing research in the Nordic countries. Available from: http://www.sykep leien.no/ikbViewer/Content/337889/SSNs\%20etiske\%20retningsli njer.pdf [accessed 10 July 2011]

[38] Miller MB. Coefficient alpha: A basic introduction from the perspectives of classical test theory and structural equation modelling. Struct Equation Model 1995; 2(3): 255-73.

(C) Flodén et al:; Licensee Bentham Open.

This is an open access article licensed under the terms of the Creative Commons Attribution Non-Commercial License (http://creativecommons.org/licenses/ by-nc/3.0/) which permits unrestricted, non-commercial use, distribution and reproduction in any medium, provided the work is properly cited. 